\title{
A Review on the Use of Landscape Indices to Study the Effects of Three-Dimensional Urban Landscape Patterns on Haze Pollution in China
}

\author{
Wen Wu ${ }^{1 *}$, Yiquan Wang1, Miao Liu², Chunlin $\mathrm{Li}^{2}$ \\ ${ }^{1}$ Jangho Architecture College, Liaoning Provincial Key Laboratory of Urban and Architectural Digital Technology, \\ Northeastern University, Shenyang 110819, China \\ ${ }^{2}$ Key Laboratory of Forest Ecology and Management, Institute of Applied Ecology, \\ Chinese Academy of Sciences, Shenyang 110016, China
}

Received: 1 October 2020

Accepted: 26 November 2020

\begin{abstract}
The interactions between landscape patterns and ecological processes have become more complex with rapid urbanization. In China, urban haze pollution has become increasingly apparent. Elucidating the relationship between urban landscape patterns and haze effects is essential for understanding the formation and development of haze and implementing effective mitigation measures. In-depth studies of the effects of three-dimensional urban landscape patterns on haze are hindered by data limitations, unreliable methods, and complex processes. This study reviews the use of landscape indices, with the aim of advancing understanding of the impacts of three-dimensional urban landscape patterns on the distribution and diffusion of haze pollution. The literature is examined to assess the status and progress of research on the use of landscape indices, and a summary of case studies in which landscape indices have been used in haze pollution modeling is presented. Furthermore, a feasible perspective based on a landscape pattern index is presented. In light of this review focusing on the relationship between urban landscape patterns and processes, new approaches for determining the spatial and temporal heterogeneity of haze distribution and diffusion and haze-prone areas, and for optimizing landscape patterns, are identified.
\end{abstract}

Keywords: urbanization, built landscape layout, haze effect, urban planning

\section{Introduction}

China's urbanization rate is expanding rapidly [1] as evidenced by an increase from $17.9 \%$ in 1978 to $60.6 \%$

*e-mail: wuwen@mail.neu.edu.cn in 2019. The growth of cities has prompted a number of environmental problems, such as the urban heat island effect along with air and water pollution [2, 3]. Haze pollution, which occurs when aerosols accumulate in the lower atmosphere, has a tremendous influence on the urban atmospheric environment [4, 5]. In 2016, the atmospheric environmental quality of 254 out of 338 Chinese cities at the prefecture level and above 
were below the national standard [6]. Atmospheric pollutants are one of the main factors that induce increased morbidity and mortality rates in urban areas [7]. In particular, haze pollution can increase mortality from respiratory, cardiovascular, and cerebrovascular diseases, chronic obstructive pulmonary disease, and coronary heart disease [8]. Initiatives such as the "Battle of Environmental Governance" (2015), "Environmental Protection Supervision" (2016), the "Blue Sky Protection Campaign" (2017), and the "Battle of Pollution Prevention and Control" (2018-2020) testify to the Chinese government's determination to solve environmental problems such as haze.

The distribution and diffusion of haze is closely related to the urban landscape pattern $[9,10]$. Rapid urbanization has led to changes in land cover and has generated significant three-dimensional characteristics of urban spatial forms that influence and complicate interactions among evolving landscape patterns and environmental processes [11]. Changes in urban land cover affect the local surface meteorological environment as well as the distribution and diffusion of pollutants. The heat island effect, caused by a change in the underlying land surface, is a prominent characteristic of a city's local climate [12]. The urban heat island effect augments temperature inversion and restricts haze diffusion. This phenomenon is related to the three-dimensional pattern of urban scale and form, which affects the scope and speed of pollutant diffusion. One plausible explanation is that tall and dense buildings reduce the wind speed in urban areas, thus increasing the concentration of atmospheric pollutants. Haze pollution is more likely to occur in the urban heat island circulation area [13], which is usually associated with the level of the urbanization gradient.

Landscape patterns highlight the combined effect of patch types and the overall landscape layout [1416]. Landscape indices are quantitative indices that reflect the composition and spatial characteristics of different landscape types. As concrete manifestations of landscape heterogeneity, they encapsulate information on the landscape pattern while also reflecting the interactions of various ecological processes at different scales. These indices have been widely used within landscape ecology to analyze the relationship between landscape patterns and processes. However, a description of the urban landscape should not be limited to two-dimensional landscape elements; rather, it should encompass both horizontality and verticality [17-20]. Because cities exhibit high spatial heterogeneity and their surface landscapes change rapidly, research that is two-dimensional is inadequate for capturing changes in ecological processes [21, 22]. This is because the characteristics of most two-dimensional landscape pattern indices are based on statistics and geometric expressions that fail to convey ecological significance. Consequently, in recent years, multidimensional landscape indices have been developed and used to describe various ecosystem services and landscape functions [23]. These three-dimensional landscape pattern indices can better represent the influence of regional characteristics on the atmospheric wind field compared with two-dimensional indices. Specifically, the construction and application of a threedimensional landscape index for studying the landscape pattern associated with haze can yield an in-depth understanding of the occurrence, development, and evolution of haze pollution.

Because pollutant emissions cannot be eliminated and topographic and meteorological factors cannot be changed [24], further studies on haze pollution mitigation are required from the perspective of optimizing the surface landscape patterns of urban areas. Some studies [25, 26] have shown that landscape indices can shed light on the atmospheric environment as it relates, for example, to the heat island effect. Accordingly, this study was aimed at filling a gap in the literature through a review of the use of landscape indices for understanding the impacts of three-dimensional urban landscape patterns on the distribution and diffusion of haze pollution. It examines the extent of research progress toward an understanding of the relationship between three-dimensional landscape patterns and the spatial and temporal heterogeneity of haze pollution. It reveals the impacts of changes in the landscape pattern on the urban atmosphere and provides a scientific basis and practical approach for alleviating existing environmental problems relating to the urban atmosphere that are mainly caused by haze. Its findings can contribute significantly to advancing the theory of pattern-process-scale interactions within landscape ecology [27]. An analysis of the relationship between landscape patterns and the temporal-spatial heterogeneity of haze can offer significant practical insights for comprehending the mechanisms underlying the formation and development of haze pollution and designing effective measures to mitigate the haze effect.

\section{Results and Discussion}

\section{The Relationship between Urban Landscape Patterns and Haze Distribution}

In the Specifications for Surface Meteorological Observation issued by the China Meteorological Administration, haze is defined as a phenomenon entailing turbid air with horizontal visibility of less than $10 \mathrm{~km}$ that is attributed to a large number of tiny dry dust particles floating uniformly in the air [28]. Urban social activities and economic production processes generate many toxic and harmful substances that enter the urban atmosphere. Inhalable particulates are one of the primary components of haze [28]. Fine particulate matter $\left(\mathrm{PM}_{2.5}\right)$ is a pollutant and a carrier of toxic substances, such as heavy metal polycyclic aromatic hydrocarbons, which are widely recognized as 
the "culprit" behind haze conditions. The air becomes polluted when the concentration of these particulates reaches harmful levels in the atmosphere. Pollution may be a more serious concern in northern or other regional cities with cold climates and high heating demands [29].

Currently, the relationship between urban landscape patterns and atmospheric environmental effects is a hot research topic. Many studies have confirmed the impacts of urban landscape patterns on atmospheric pollution [30-34]. The results have been applied in ecologically-friendly urban landscape designs. For example, efforts have been made to reduce atmospheric $\mathrm{PM}_{2.5}$ content through the design of urban green spaces [35]. However, there are few existing studies on the relationship between urban landscape patterns and their effects on atmospheric haze. Moreover, most studies on urban landscape types have focused on specific land use types and have entailed two-dimensional landscape patterns, such as green space, water, and residential landscapes. By contrast, few studies have attempted to quantify the effects of three-dimensional landscape patterns, especially the heat island effect associated with air pollution.

The diffusion of atmospheric pollutants, which is associated with patterns of urban heat island circulation, is closely linked to the spatial form and structure of a three-dimensional urban landscape [36] in the following ways. First, the different attributes of landscape patterns directly induce changes in local haze pollutants. Second, studies have shown that prevailing types of land use and architectural patterns could affect surface temperature [37-40], while the morphological characteristics of urban street canyons could affect wind speed and direction [41]. Therefore, changes in the structural features of land surfaces indirectly affect the local climate, which in turn indirectly impacts on the non-uniformity of the distribution of energy and matter, the transport of particles, and the spatial distribution of urban atmospheric pollutants [36]. Furthermore, the urban landscape pattern influences the proportion of surface energy inputs and outputs and, consequently, the thermal environmental change trend. Thus, urban heat island circulation and haze diffusion tend to exacerbate each other [42].

A variety of scales need to be considered in explorations of the relationship between urban landscape patterns and atmospheric processes [43]. Analyses of haze pollution at different scales require different methods. Table 1 presents a summary of models used to assess typical pollutant diffusion at different scales. In general, while the scale of diffusion of urban haze pollution within the atmospheric environment is low, it is inevitably affected by largescale atmospheric movements [44]. It is noteworthy that atmospheric numerical models have gradually evolved from the level of single micro-scale studies to regional multi-scale studies [45]. For the detailed characteristics that should reflect the impact of micro-scale building disturbances, ISC3 (Industrial Sources Complex, Version 3), CFD (Computational Fluid Dynamics, [46]), CALINE (California Line Source Dispersion Model, [47, 48]), TNO-Traffic [49], STREET-SRI (i.e. Stanford Research Institute, [50]) and OSPM (Operational Street Pollution Model, [51]) models are commonly used [52]. Mesoscale meteorological models WRF (Weather Research and Forecast Model), RAMS (Regional Atmospheric Modeling System), ARPS

Table 1. Models of typical pollutant diffusion at different scales.

\begin{tabular}{|c|c|c|c|c|}
\hline Method & Data sources & Theoretical basis & Advantages & Disadvantages \\
\hline $\begin{array}{l}\text { Inversion of MODIS } \\
\text { remote sensing im- } \\
\text { ages [67-69] }\end{array}$ & $\begin{array}{l}\text { MODIS aerosol } \\
\text { products }\end{array}$ & $\begin{array}{l}\text { Remote sensing } \\
\text { inversion }\end{array}$ & $\begin{array}{l}\text { Wide coverage, } \\
\text { economic efficiency, } \\
\text { long-term monitoring }\end{array}$ & $\begin{array}{l}\text { No strong correlation between aerosol } \\
\text { optical depth (AOD) and atmospheric } \\
\text { pollutant concentration, low spatial } \\
\text { resolution }\end{array}$ \\
\hline $\begin{array}{l}\text { Spatial interpolation } \\
\text { method [70] }\end{array}$ & $\begin{array}{l}\text { Pollution } \\
\text { concentration data } \\
\text { of space } \\
\text { monitoring stations }\end{array}$ & $\begin{array}{l}\text { Establishment of } \\
\text { approximation } \\
\text { function }\end{array}$ & $\begin{array}{l}\text { Simple principle, } \\
\text { convenient operation, } \\
\text { wide scope of } \\
\text { application }\end{array}$ & $\begin{array}{l}\text { Insufficient density of monitoring } \\
\text { stations, less consideration } \\
\text { of influential factors, easy to } \\
\text { magnify extreme pollution } \\
\text { concentration changes }\end{array}$ \\
\hline $\begin{array}{c}\text { Land-use regression } \\
\text { (LUR) }[54,71,72]\end{array}$ & $\begin{array}{l}\text { Air pollution } \\
\text { monitoring data, } \\
\text { land use data }\end{array}$ & $\begin{array}{l}\text { Statistical regression } \\
\text { model, GIS } \\
\text { algorithm }\end{array}$ & $\begin{array}{l}\text { Low data requirements, } \\
\text { wide scope of } \\
\text { application, high } \\
\text { resolution, } \\
\text { comprehensive factors }\end{array}$ & $\begin{array}{l}\text { Variable selection is subjective. It is } \\
\text { difficult to migrate models in time and } \\
\text { space. It is difficult to quantitatively } \\
\text { analyze the influencing factors. }\end{array}$ \\
\hline $\begin{array}{l}\text { Atmospheric numeri- } \\
\text { cal model [73-77] }\end{array}$ & $\begin{array}{l}\text { Observation data } \\
\text { of atmospheric } \\
\text { pollutant } \\
\text { concentration, } \\
\text { radar and remote } \\
\text { sensing observation } \\
\text { data, topographic } \\
\text { data, emission data }\end{array}$ & $\begin{array}{l}\text { Theory of turbulent } \\
\text { diffusion in boundary } \\
\text { layer, theory of air } \\
\text { chemistry }\end{array}$ & $\begin{array}{c}\text { Simple structure of } \\
\text { small-scale model, } \\
\text { fast calculation speed, } \\
\text { low requirements for } \\
\text { basic data, coupling of } \\
\text { small and medium scale } \\
\text { models }\end{array}$ & $\begin{array}{l}\text { Small-scale model cannot effectively } \\
\text { simulate the complex air pollution } \\
\text { process. }\end{array}$ \\
\hline
\end{tabular}


(The Advanced Regional Prediction System), and air quality model systems WRF-CHEM (Weather Research Forecast-Chemistry, [53]), CMAQ (Community Multiscale Air Quality Model), NAQPMS (Nested Air Quality Prediction Modeling System) use multi-scale nested grids, which can systematically simulate the interaction between pollutant emissions, meteorological conditions, chemical conversion and dry-wet removal at various scales, making them suitable for meteorological problems at regional and urban scales [53,54]. Some studies [55] have coupled mesoscale and microscale models to simulate boundary layer values at different scales with good results.

In recent years, the Environment for Visualizing Images (ENVI-met) program, version V4.0 or above, which covers pollutant deposition, wind and thermal environments and optimal plant allocation within a computational fluid dynamics model, has been widely used in studies at the block scale. Such block-scale studies on the impacts of three-dimensional urban patterns on haze diffusion in China have mostly focused on single landscape types, such as commercial blocks [31], residential areas, and three-dimensional traffic [56]. Table 2 presents basic information on four typical pollutant diffusion models at the block scale: ENVI-met, FLUENT, the Micro Scale Air Pollution Model [57, 58]), and the OSPM [59]. The findings of a comparative analysis of working principles, operation flows, and spatiotemporal resolution revealed that the simulation effects of the ENVI-met model on pollution diffusion are superior to those of other models [60]. Detailed analyses of different surface landscapes and heat island and haze island processes have been carried out [61-65]. However, few studies have attempted to develop indices or method of urban modeling that can be applied in urban planning and design that are aligned with the overall urban architecture. At the same time, the impact of landscape patterns on haze diffusion is mainly based on model simulation [66]. Therefore, there is an urgent need to strengthen field measurements, especially in relation to meteorological conditions.

\section{Application of Landscape Indices in the Study of Urban Haze Pollution}

Methods for analyzing landscape patterns include landscape indices, spatial analysis, and landscape models that are mostly based on different kinds of goaloriented landscape data [78]. Landscape indices are easy to calculate, so it is appropriate and feasible to use them to explore the impacts of urban landscape patterns on haze [79]. Urban haze pollution studies mainly use data on local pollutant concentrations obtained from environmental monitoring stations. However, the relationship between atmospheric particulate concentrations and landscape patterns remains ambiguous because of the paucity of environmental monitoring stations, incomplete coverage, and low spatial resolution. Moreover, its portrayal is usually confined to qualitative descriptions of the spatial distribution of pollutant concentrations or temporal variations in pollution levels.

Studies have generally focused on the impacts of land use changes and landscape patterns on haze pollution and have tended to be quantitative and refined. The density, shape, aggregation, and dispersion of spatial patterns are typically described in terms of traditional landscape pattern indices based on the use of landscape types. Subsequently, correlation and multiple stepwise regression analyses of atmospheric particulate concentrations are performed. The findings of these studies are relatively clear. Table 3 presents a summary of applications of landscape indices relating to haze pollution modeling in China. Urban morphologies and landscape patterns affect atmospheric particulate pollution, which is revealed by landscape indices. However, there are many traditional landscape indices that are self-correlated. The challenge entailed in using these methods concerns the scientific selection of landscape indices that accurately reflect ecological conditions [80]. At the same time, environmental impact factors, such as the point pollution source, traffic, and meteorological conditions can be accounted for in the landscape indices.

Table 2. Basic information covered in four typical pollutant diffusion models at the block scale.

\begin{tabular}{|c|c|c|c|c|}
\hline $\begin{array}{l}\text { Model and } \\
\text { version }\end{array}$ & Style & $\begin{array}{l}\text { Temporal-spatial } \\
\text { resolution }\end{array}$ & Modules & Typical applications \\
\hline $\begin{array}{l}\text { ENVI-met } \\
\text { V4.0 }\end{array}$ & CFD model & $\begin{array}{c}0.5 \mathrm{~m} \\
1-5 \mathrm{~s}\end{array}$ & $\begin{array}{l}\text { Atmosphere, buildings, vegetation, } \\
\text { soil, radiation and pollutant }\end{array}$ & $\begin{array}{l}\text { Pollutants diffuse, wind environment, } \\
\text { thermal environment, } \\
\text { building energy, optimizing allocation } \\
\text { of vegetation }\end{array}$ \\
\hline $\begin{array}{l}\text { FLUENT } \\
\text { V6.3 }\end{array}$ & CFD model & $\begin{array}{l}1-2 \mathrm{~m} \\
1-5 \mathrm{~s}\end{array}$ & $\begin{array}{l}\text { Atmosphere, buildings, soil, } \\
\text { radiation and pollutant }\end{array}$ & $\begin{array}{l}\text { Pollutants diffuse, thermal } \\
\text { environment, optimizing allocation of } \\
\text { vegetation }\end{array}$ \\
\hline $\begin{array}{l}\text { MISKAM } \\
\text { V6.1 [57] }\end{array}$ & CFD model & $\begin{array}{c}1-2 \mathrm{~m} \\
1 \mathrm{~h}\end{array}$ & $\begin{array}{l}\text { Wind field, simple vegetation, no } \\
\text { thermal simulation }\end{array}$ & Pollutants diffuse, wind environment \\
\hline $\begin{array}{c}\text { OSPM } \\
\text { V5.1.90[59] }\end{array}$ & $\begin{array}{l}\text { Semi-empirical } \\
\text { model }\end{array}$ & $\begin{array}{c}0.5 \mathrm{~m} \\
1 \mathrm{~h}\end{array}$ & $\begin{array}{c}\text { Street airflow, turbulence caused } \\
\text { by traffic, no vegetation or thermal } \\
\text { simulation }\end{array}$ & Pollutants diffuse \\
\hline
\end{tabular}


Table 3. Case studies of landscape indices used in haze pollution modeling in China.

\begin{tabular}{|c|c|c|c|}
\hline Typical area & $\begin{array}{c}\text { Model } \\
\text { variable }\end{array}$ & Landscape indices & Main results \\
\hline $\begin{array}{c}\text { Beijing } \\
{[81]}\end{array}$ & $\begin{array}{c}\mathrm{PM}_{2.5} \\
\text { concentrations }\end{array}$ & $\begin{array}{l}\text { Road length density (RLD), Road area } \\
\text { density (RAD), Construction area density } \\
\text { (CAD), Construction height density (CHD), } \\
\text { Construction volume density (CVD), } \\
\text { Construction otherness (CO), Vegetation } \\
\text { area density (VAD), Water area density } \\
\text { (WAD), Water fragmentation (WF) }\end{array}$ & $\begin{array}{l}\text { Results demonstrated that RLD, RAD, CAD, CHD, } \\
\text { CVD, CO, and VAD have positive impacts on the } \\
\mathrm{PM}_{2.5} \text { concentrations, whereas WAD and WF have } \\
\text { negative impacts on the } \mathrm{PM}_{2.5} \text { concentrations. }\end{array}$ \\
\hline Shenzhen [32] & $\begin{array}{c}\mathrm{PM}_{2.5} \\
\text { concentrations }\end{array}$ & ED, Fragment & $\begin{array}{c}\text { The impact of ED on } \mathrm{PM}_{2.5} \text { concentration varies } \\
\text { with the size of the buffer zone. At landscape level, } \\
\text { fragment had a significant relationship with } \mathrm{PM}_{2.5} \\
\text { pollution. }\end{array}$ \\
\hline \begin{tabular}{|c|} 
Shenyang $[30$, \\
$82]$
\end{tabular} & $\begin{array}{c}\mathrm{PM}_{10} \\
\text { concentrations }\end{array}$ & $\begin{array}{l}\text { Building coverage ratio (BCR), } \\
\text { Height/Wide }\end{array}$ & $\begin{array}{l}\text { The decreasing trend of pollutant mass concentration } \\
\text { and the uniformity of spatial distribution are } \\
\text { significantly affected by the BCR in horizontal } \\
\text { sections at different heights. }\end{array}$ \\
\hline $\begin{array}{c}\text { Nanchang } \\
{[34]}\end{array}$ & $\begin{array}{l}\mathrm{PM}_{2.5} \text { and } \mathrm{PM}_{10} \\
\text { concentrations }\end{array}$ & $\begin{array}{l}\text { Construction land percent of landscape } \\
\text { (C-PLAND), Construction land of shannon } \\
\text { diversity (C-SHDI), Construction land of } \\
\text { separation index (C-FI) }\end{array}$ & $\begin{array}{l}\text { At class level, the C-PLAND and C-SHDI were } \\
\text { positively correlated with the concentration of } \mathrm{PM}_{2.5} \\
\text { and } \mathrm{PM}_{10} \text {, C-FI was negatively correlated with the } \\
\text { concentration of } \mathrm{PM}_{2.5} \text { and } \mathrm{PM}_{10} \text {. }\end{array}$ \\
\hline Shanghai [37] & $\begin{array}{l}\text { Land surface } \\
\text { temperture } \\
\quad(\mathrm{LST})\end{array}$ & $\begin{array}{c}\text { BCR, Mean architecture height (MAH), } \\
\text { Mean architecture height standard deviation } \\
\text { (AHSD), Mean architecture projection area } \\
\text { (MAPA) }\end{array}$ & $\begin{array}{l}\text { With the LST, the BCR exhibits a monotonic positive } \\
\text { correlation, the MAH and AHSD show a stepwise } \\
\text { negative correlation, and the MAPA shows } \\
\text { a combination of positive and negative correlation. }\end{array}$ \\
\hline Beijing [83] & $\begin{array}{c}\text { Temperture, } \\
\text { humidity, wind } \\
\text { speed }\end{array}$ & $\begin{array}{c}\text { Landscape volume density (LVD), } \\
\text { Landscape height density (LHD), } \\
\text { Landscape height range (LHR), Sky view } \\
\text { factor (SVF) }\end{array}$ & $\begin{array}{c}\text { Regions with higher urban 3D LVD, or higher LHD, } \\
\text { or higher LHR suffered from higher temperature, } \\
\text { lower humidity and wind speed. The lower the SVF, } \\
\text { the higher the temperature and the lower the wind } \\
\text { speed. }\end{array}$ \\
\hline $\begin{array}{l}\text { Hong Kong } \\
{[24,25]}\end{array}$ & \begin{tabular}{|l|} 
Urban heat \\
island intensity \\
(UHII)
\end{tabular} & SVF & $\begin{array}{l}\text { Generally, the higher the SVF is, the stronger the UHI } \\
\text { intensity is, but the research in Hong Kong shows } \\
\text { that the two have a significant negative correlation. }\end{array}$ \\
\hline
\end{tabular}

Urban spatial forms evidence strong threedimensional characteristics compared with natural landscapes [83]. Because of the complexity of material and energy exchange processes, a two-dimensional method alone cannot provide an accurate depiction of changes occurring within contemporary threedimensional urban spaces. To determine whether an urban planning layout is reasonable, it is necessary to examine the vertical heterogeneity of the urban landscape [84]. Three-dimensional landscape indices are commonly used to evaluate aspects of the urban atmospheric environment, including the height-width ratio of street canyons, the sky visibility factor, and the frontal area index (Table 4). The sky visibility factor and the height-width ratio of street canyons are used to measure the degree of radiation shielding offered by buildings and vegetation above specific locations, while the frontal area index is used to evaluate the degree to which air movement is blocked near the surface of the building elevation. Statistical methods that reflect the relationship between the landscape pattern and atmospheric pollutants have been used to construct a regression model of the three-dimensional landscape index and the concentration of atmospheric pollutants. The results of the model show that the heights of the buildings on both sides of the street canyon, space combination, and the shapes of buildings determine the local flow field in the street canyon, which greatly influences the diffusion of inhalable particulates [30]. The sky visibility factor is related to the UHII [26]. A maximum UHII model, namely Tu-r $(\max )=7.45+3.971 n$ (height-to-width ratio) has been used to determine the intensity of the heat island at night. Although R2 can reach a value of 0.89 when the model is used to predict UHII in European and American cities, different results are obtained for other urban thermal environments under varying climatic conditions $[85,86]$. One possible reason is that this relationship is linked to the spatial form of urban landscapes in the study area, and a single index cannot respond effectively to the complex atmospheric environment. Consequently, a generalized research conclusion is not possible.

The results of an assessment of atmospheric pollutants derived from scenario setting and using a three-dimensional index model must correspond to 
Table 4. Two- and three-dimensional landscape pattern indices for characterizing urban landscape patterns.

\begin{tabular}{|c|c|c|}
\hline Index name & Basic description & Ecological significance \\
\hline \begin{tabular}{c|} 
Average \\
building height \\
{$[87]$}
\end{tabular} & $\begin{array}{l}\text { Reflects the overall building } \\
\text { height and the urban expansion } \\
\text { in the vertical direction. }\end{array}$ & $\begin{array}{l}\text { The higher the average building height, the higher the building height, and the } \\
\text { more the city will expand vertically. }\end{array}$ \\
\hline $\begin{array}{l}\text { Building } \\
\text { coverage ratio } \\
{[84]}\end{array}$ & $\begin{array}{l}\text { The ratio of building base area to } \\
\text { land area. }\end{array}$ & $\begin{array}{l}\text { Building density is positively correlated with haze pollutant concentration, and } \\
\text { affects near-surface wind speed and atmospheric diffusion. It can reflect the } \\
\text { degree of building coverage to a certain extent. }\end{array}$ \\
\hline $\begin{array}{l}\text { Patch density } \\
\quad[87]\end{array}$ & $\begin{array}{l}\text { The ratio of the number of } \\
\text { building patches to the area. }\end{array}$ & $\begin{array}{l}\text { Patch density is used to reflect the fragmentation degree of patches. The larger } \\
\text { the value, the greater the fragmentation degree of landscape. }\end{array}$ \\
\hline $\begin{array}{l}\text { Aggregation } \\
\text { index [84] }\end{array}$ & $\begin{array}{l}\text { An index reflecting the } \\
\text { aggregation and dispersion of } \\
\text { patches in the landscape. }\end{array}$ & $\begin{array}{l}\text { When the patches are fully dispersed, the index value is }-1 \text {, when they are } \\
\text { randomly distributed, the index value is } 0 \text {, when they are aggregated, the index } \\
\text { value is } 1 .\end{array}$ \\
\hline $\begin{array}{l}\text { Standard } \\
\text { deviation of } \\
\text { landscape } \\
\text { height [37] }\end{array}$ & $\begin{array}{l}\text { Reflects the variation of the } \\
\text { height of urban building land- } \\
\text { scape in a certain range. }\end{array}$ & $\begin{array}{l}\text { The greater the standard deviation of landscape height, the greater the variation } \\
\text { of building height. The variation of building height will interfere with the } \\
\text { process of atmospheric diffusion, and then affects the spatial distribution of } \\
\text { atmospheric pollutants. }\end{array}$ \\
\hline $\begin{array}{c}\text { Floor area ratio } \\
{[84]}\end{array}$ & $\begin{array}{l}\text { The ratio of total floor area to } \\
\text { land area. }\end{array}$ & $\begin{array}{c}\text { Complex building facades and roofs change the spatial distribution of } \\
\text { atmospheric pollutants in urban areas. Floor area ratio can reflect building } \\
\text { coverage ratio in three-dimensional space, and thus affects the atmospheric } \\
\text { diffusion. }\end{array}$ \\
\hline $\begin{array}{c}\text { Sky view factor } \\
{[87]}\end{array}$ & $\begin{array}{c}\text { Often used to measure the degree } \\
\text { to which radiation transmis- } \\
\text { sion at a particular location is } \\
\text { blocked. }\end{array}$ & $\begin{array}{l}\text { The range of sky view factor is from } 0 \text { to } 1.0 \text { means that the sky is completely } \\
\text { blocked by buildings, trees and other things, so that all radiation is blocked. } 1 \\
\text { means that the sky is not blocked by obstacles, and the ground will receive (or } \\
\text { emit) all radiation. It is an index used to reflect the near-surface air temperature } \\
\text { (or surface temperature). }\end{array}$ \\
\hline $\begin{array}{l}\text { Landscape } \\
\text { height density } \\
{[83]}\end{array}$ & $\begin{array}{l}\text { The ratio of the total height of all } \\
\text { patches in the landscape to the } \\
\text { area of the area. }\end{array}$ & $\begin{array}{l}\text { It can express the average height level and spatial difference of landscape in } \\
\text { three-dimensional space. The higher the landscape height density, the higher the } \\
\text { regional temperature, the lower the humidity and the lower the wind speed. }\end{array}$ \\
\hline $\begin{array}{l}\text { Landscape } \\
\text { height range } \\
\quad[83]\end{array}$ & $\begin{array}{l}\text { The difference between } \\
\text { the highest and lowest height } \\
\text { values of patches in } \\
\text { the landscape. }\end{array}$ & $\begin{array}{c}\text { The higher the fluctuation of landscape, the higher the vertical height of the } \\
\text { interaction between urban landscape and atmospheric environment. The larger } \\
\text { the landscape height range, the higher the regional temperature, the lower the } \\
\text { humidity and the lower the wind speed. }\end{array}$ \\
\hline $\begin{array}{l}\text { Highest land- } \\
\text { scape indices } \\
\quad[83]\end{array}$ & $\begin{array}{l}\text { The ratio of the highest patch } \\
\text { height to the total landscape } \\
\text { height. }\end{array}$ & $\begin{array}{c}\text { The larger the highest landscape indices, the larger the spatial range } \\
\text { of interaction between urban three-dimensional landscape and atmospheric } \\
\text { environment. }\end{array}$ \\
\hline \begin{tabular}{c|} 
Landscape \\
volume density \\
{$[83]$}
\end{tabular} & $\begin{array}{l}\text { The ratio of the sum of the } \\
\text { olumes of all patches to the area } \\
\text { of the landscape. }\end{array}$ & $\begin{array}{l}\text { The density of landscape volume reflects the degree of spatial congestion of the } \\
\text { landscape in the region. The larger the Landscape volume density, the larger } \\
\text { the range of contact with the atmosphere, and the stronger the degree of energy } \\
\text { exchange between the landscape and the atmosphere. }\end{array}$ \\
\hline $\begin{array}{l}\text { Impermeable } \\
\text { surface ratio } \\
{[88]}\end{array}$ & $\begin{array}{l}\text { The ratio of impermeable surface } \\
\text { to land area. }\end{array}$ & $\begin{array}{l}\text { The impermeable surface can absorb solar radiation rapidly and release most } \\
\text { of it into the atmosphere in the form of sensible heat flux. This is an important } \\
\text { index to measure the degree of urbanization and the intensity of heat island. }\end{array}$ \\
\hline $\begin{array}{l}\text { Frontal area } \\
\text { index }[89]\end{array}$ & $\begin{array}{l}\text { Reflects the strength of the } \\
\text { shielding effect of the building } \\
\text { surface on the air movement in } \\
\text { the direction of the incoming } \\
\text { wind. }\end{array}$ & $\begin{array}{l}\text { Haze often forms in static weather conditions. With the increase of wind speed, } \\
\text { the intensity of haze pollution gradually decreases. Frontal area index is mainly } \\
\text { used to measure the degree of urban wind environment affected by buildings. }\end{array}$ \\
\hline $\begin{array}{c}\text { Building and } \\
\text { crown ratio [81] }\end{array}$ & $\begin{array}{l}\text { The ratio of the basement area } \\
\text { to the vertical projection area of } \\
\text { tree crown. }\end{array}$ & $\begin{array}{l}\text { The combination of building occupancy ratio with crown coverage can reflect } \\
\text { the impact of the two ratios of the urban landscape types, which have great } \\
\text { influence on atmospheric diffusion, on air pollutants. }\end{array}$ \\
\hline $\begin{array}{l}\text { Building shape } \\
\text { coefficient }[90]\end{array}$ & $\begin{array}{l}\text { The ratio of the outer surface } \\
\text { of a building to the volume } \\
\text { enclosed by the atmosphere. }\end{array}$ & $\begin{array}{l}\text { The outer surface area occupied by unit building volume is used to reflect the } \\
\text { size of heat dissipation area and energy consumption of building space. The } \\
\text { larger the value, the larger the heat dissipation area per unit building space, and } \\
\text { the higher the building energy consumption. The results show that it is related to } \\
\text { air quality to some extent. }\end{array}$ \\
\hline
\end{tabular}


a specific landscape pattern. In this context, landscape indices can provide quantitative descriptions of this landscape pattern. Three-dimensional landscape indices can reveal the urban landscape pattern corresponding to the characteristics of haze pollution. Moreover, they can be used to guide the feasible perspective of a landscape pattern for mitigating haze pollution.

\section{The Limitations of Existing Studies}

Acquiring pollution data of high spatial and temporal resolution and large-scale spatial data relating to environmental factors are key challenges faced when conducting assessments of urban-scale haze pollution. The conduct of field monitoring in conjunction with spatial analyses of landscape patterns can significantly improve the degree of spatialization and facilitate the refinement of a feasible perspective on landscape patterns that are optimized for reducing haze pollution.

Many complex factors restrict the diffusion, migration, and transformation of urban haze. Moreover, there is no consensus on the impacts of landscape patterns on haze. Limited data, unreliable methods, and complex processes impede the study of the effects of urban three-dimensional landscape patterns on haze, thereby constraining an understanding of their interactions. Studies that focus on a particular landscape or on two-dimensional land use cannot adequately explain the spatial and temporal heterogeneity of the complex urban haze effect.

\section{A Feasible Perspective on Landscape Patterns for Mitigating Haze Pollution}

A feasible perspective of landscape pattern for mitigating haze pollution draws on the theory and methods of landscape ecology. Following an analysis and evaluation of a landscape pattern and its associated ecological process, it can be adjusted to maximize its overall value [91]. Optimization of the landscape pattern for mitigating haze pollution requires an understanding of its relationship with haze distribution and diffusion as well as the classification and evaluation of the landscape and the development of pattern feasible strategies for different functional units of the landscape.

Most studies focusing on the mitigation of haze pollution and the optimization of the urban landscape pattern have been conducted at the block scale and have examined one or several specific landscape elements/functional areas. In the area of architectural landscapes, researchers have examined the effects of architectural forms and layouts, building materials, and the directions of street canyons on local $\mathrm{PM}_{25}$ and $\mathrm{PM}_{10}$ concentrations $[92,93]$. Those studying transportation have mainly focused on horizontal and vertical observations of fine particulate concentrations on urban main roads and viaducts [94]. In the area of green space, researchers have quantitatively analyzed the influence on $\mathrm{PM}_{2.5}$ concentrations from plant species, the crown structure, and the size and shape of green patches, paying less attention to the underlying structure of the overall landscape. Moreover, the effect

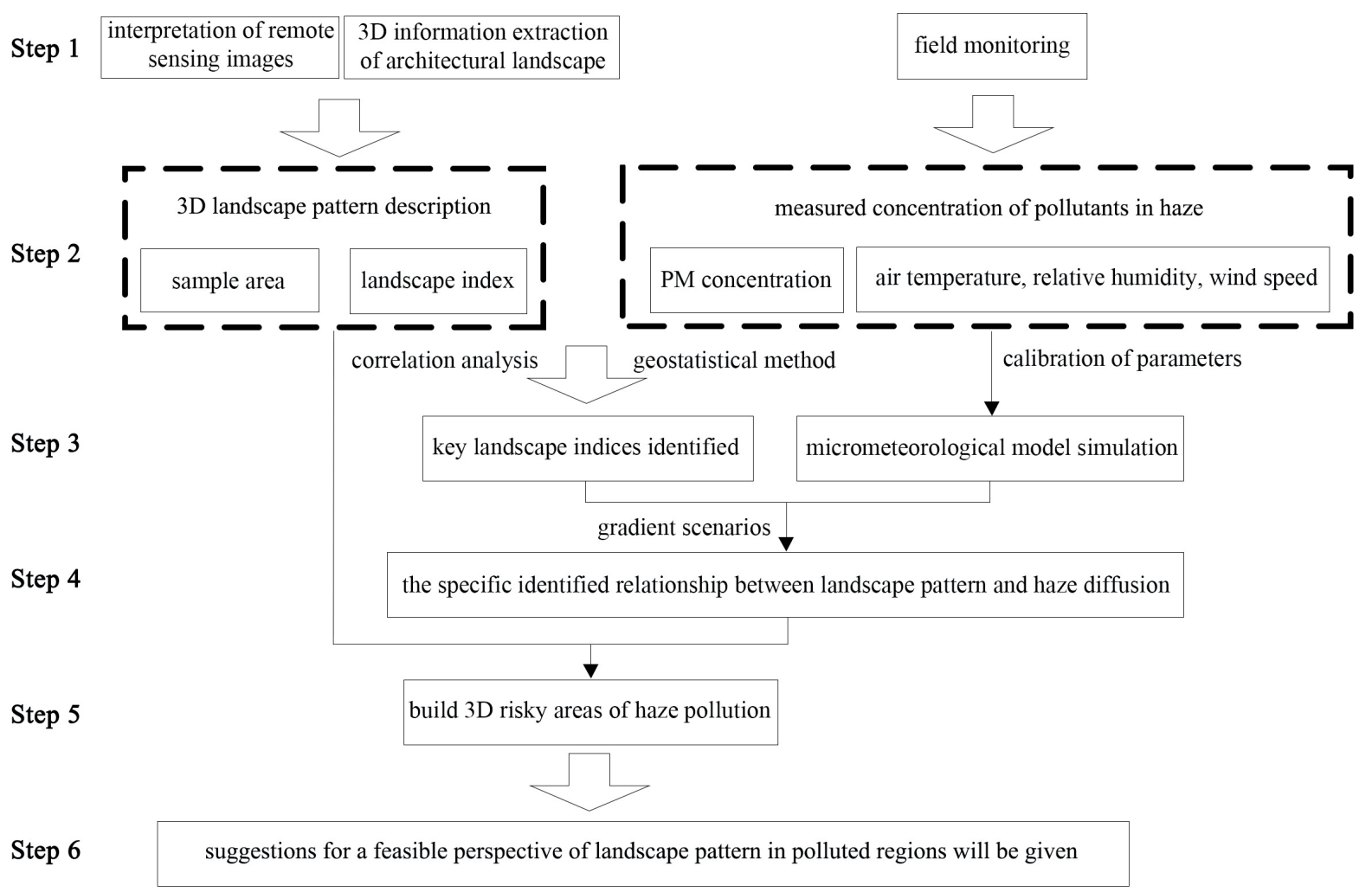

Fig. 1. A flow chart depicting the process of optimizing landscape patterns for mitigating haze pollution. 
of vegetation on pollutant concentrations remains uncertain, requiring further analysis in combination with multi-scale methods [95, 96]. Last, studies on water have focused on the influence of urban rivers and lakes on the surrounding thermal environment, and on atmospheric circulation driven by the heat island effect, which indirectly influences the distribution and diffusion of atmospheric particulates.

In view of the above limitations, this study provides a feasible perspective relating to the design of a landscape pattern that is based on a landscape pattern index. Fig. 1 presents a flow chart showing the steps entailed in this process. In the first step, the PM concentration on the ground and at different levels is monitored using the mobile observation method and an unmanned aerial vehicle platform [56, 94]. Subsequently, the 3D landscape indices for haze pollution are filtered, and spatial distribution maps of the selected landscape indices at varying heights are constructed [81]. In the third step, statistical methods, notably stepwise regression analysis, are used to identify key influencing factors of haze pollution, considering the haze concentration as the dependent variable and the landscape indices as the independent variables [97]. In the fourth step, the parameters of the micrometeorological model are calibrated and verified. Subsequently, the gradient scenarios for each key index are used to simulate the concentrations of nearsurface haze pollution for different scenarios under typical weather conditions [98]. The specific response relationship between the key influencing factor and local haze diffusion can thus be determined [99]. In step 5, spatial distribution maps of haze at city and block scales are developed, divided into different regions according to the risk intensity of haze pollution. The relevant attribute information is managed using the ArcGIS software. Finally, in the sixth step, the landscape pattern characteristics for each degree of risky regions are summarized [37]. Accordingly, recommendations on an appropriate landscape pattern for heavily polluted areas can be provided in terms of building types and density and other landscape indices associated with safe regions [81].

\section{Conclusions}

This study provides a new and feasible perspective for describing haze conditions in relation to landscape patterns. Moreover, it provides valuable inputs for urban planning through the methodology proposed for determining the haze risk mechanism from the perspective of landscape indices, such as the landscape shape index, the building coverage ratio, and the sky view factor. Case studies conducted in this field within China were identified and analyzed by comparing progress relating to the application of the existing haze diffusion model with a methodology entailing threedimensional landscape pattern indices. Consequently, a feasible perspective based on a landscape pattern index was formulated as an attempt to develop a universal method for identifying the risk of haze at the city scale. This methodology can contribute significantly to advancing the theory of pattern-processscale interactions within landscape ecology and to the provision of technical support for using the threedimensional landscape index to assess haze pollution.

Nevertheless, this review has revealed some limitations within the existing literature. By contrast, the use of remote sensing images, three-dimensional building information, and unmanned aerial vehicle platforms, combined with field monitoring and micrometeorological numerical simulation methods, enables the selection of key landscape indices. These indices reveal the degree of local haze pollution. Consequently, the relationship between a three-dimensional landscape pattern and atmospheric particulate concentration can be elucidated and the risk of haze pollution in the area under investigation can be identified. The findings of this review suggest a new and potentially fruitful approach for clarifying the spatial and temporal heterogeneity of the characteristics of haze distribution and diffusion, identifying risk areas for haze, and optimizing landscape patterns to mitigate haze pollution.

\section{Acknowledgements}

Funding for this project was provided by the National Natural Science Foundation of China (Nos. 41871162 and 41871192) and the Fundamental Research Funds for the Central Universities of China (No. N2011005).

\section{Conflict of Interest}

The authors declare no conflict of interest.

\section{References}

1. Chinese Academy of Sciences. Report on New Urbanization of China in 2012. 2012 [In Chinese].

2. ZHOU W.Q., WANG K., YU W.J., LI W.F., HAN L.J., QIAN Y.G. Understanding the social and ecological connections between cities and surrounding regions for unban and regional sustainability. Chinese Acta Ecol. Sinica, 37, 5238, 2017 [In Chinese].

3. LI C.L., LIU M., HU Y.M., SHI T., ZONG M., WALTER M.T. Assessing the Impact of Urbanization on Direct Runoff Using Improved Composite CN Method in a Large Urban Area. Int. J. Env. Res. Pub. He., 15, 775, 2018.

4. GROMKE C., JAMARKATTEL N., RUCK B. Influence of roadside hedgerows on air quality in urban street canyons. Atmos. Environ., 139, 75, 2016.

5. ZHANG W.Z., WANG H., ZHANG X.Y., PENG Y., ZHONG J.T., WANG Y.Q., ZHAO Y.F. Evaluating the contributions of changed meteorological conditions and emission to substantial reductions of $\mathrm{PM}_{2.5}$ concentration 
from winter 2016 to 2017 in Central and Eastern China. Sci. Total Environ., 716, 136892, 2020.

6. Ministry of Ecology and Environment of the People's Republic of China. Announcement on China's Environmental Status in 2016. 2017 [In Chinese].

7. GUSTAFSSON A., KRAIS A.M., GORZSAS A., LUNDH T., GERDE P. Isolation and characterization of a respirable particle fraction from residential house-dust. Environ. Res., 161, 284, 2018.

8. RAGER J.E., STRYNAR M.J., LIANG S., MCMAHEN R.L., RICHARD A.M., GRULKE C.M., WAMBAUGH J.F., ISAACS K.K., JUDSON R., WILLIAMS A.J., SOBUS J.R. Linking high resolution mass spectrometry data with exposure and toxicity forecasts to advance highthroughput environmental monitoring. Environ. Int., 88, 269, 2016.

9. KARRA S., MALKI-EPSHTEIN L., NEOPHYTOU M.K.A. Air flow and pollution in a real, heterogeneous urban street canyon: A field and laboratory study. Atmos. Environ., 165, 370, 2017.

10. CHEN L.D., SUN R.H., LIU H.L. Eco-environmental effects of urban landscape pattern changes: progress, problems, and perspectives. Chinese Acta Ecol. Sinica, 33, 1042, 2013 [In Chinese].

11. WHITE R., ULJEE I., ENGELEN G. Integrated modelling of population, employment and land-use change with a multiple activity-based variable grid cellular automaton. Int. J. Geogr. Inf. Sci., 26, 1251, 2012.

12. WU Z.W., SHAN H.N., WANG Y.H. Several kinds of landscape in the process of two complete ash haze $\mathrm{PM}_{25}$ monitoring and analysis. Environ. Sci. Technol., 38, 299, 2015 [In Chinese].

13. CAO C., LEE X., LIU S.D., SCHULTZ N., XIAO W., ZHANG M., ZHAO L. Urban heat islands in China enhanced by haze pollution. Nat. Commun., 7, 12509, 2016.

14. QIAN Y., ZHOU W., YU W., PICKETT S.T.A. Quantifying spatiotemporal pattern of urban greenspace: new insights from high resolution data. Landsc. Ecol., 30, 1165, 2015.

15. WU W., LI Y.H., HU Y.M., CHANG Y., XIONG Z.P. Anthropogenic effect on forest landscape pattern and Cervidae habitats in northeastern China. J. Geog. Sci., 29, 1098, 2019.

16. LI C.L., LIU M., HU Y.M., ZHOU R., LIU C. Spatial distribution characteristics of gaseous pollutants and particulate matter inside a city in the heating season of Northeast China. Sustain. Cities Soc., 61, 102302. 2020.

17. WU Z.F., WEI L.Z., LV Z.Q. Landscape pattern metrics an empirical study from 2-D to 3-D. Phys. Geog., 33, 383, 2012.

18. GETZNER M., FARBER B., YAMU C. 2D versus 3D the relevance of the mode of presentation for the economic valuation of an alpine landscape. Sustainability, 8, 591, 2016.

19. ZHANG X.F., WANG Y.L., LI Z.G., LI W.F., YE M.T. Prelininary theory of three-dimensional landscape ecology. Chinese Acta Ecol. Sinica, 27, 2972, 2007 [In Chinese].

20. GONG J.P., HU Y.M., LIU M., CHANG Y., BU R.C., XIONG Z.P., LI C.L. Review on three-dimensional expansion and its atmosphere environmental effects of urban landscape. Chinese J. Ecol., 34, 562, 2015 [In Chinese].

21. UUEMAA E., MANDER Ü., MARJA R. Trends in the use of landscape spatial metrics as landscape indicators: A review. Ecol. Indic., 28, 100, 2013.
22. WU W., LI C.L., LIU M., HU Y.M., XIU C.L. Change of impervious surface area and its impacts on urban landscape: an example of Shenyang between 2010 and 2017. Ecosyst. Health Sust., 6, 1, 2020.

23. ZHANG C.Y., HU Y.M., LIU M., LI C.L. Research progress on three-dimensional pattern in landscape ecology. Chinese J. Appl. Ecol., 30, 4353, 2019 [In Chinese].

24. WANG Z.B., FANG C.L. Spatial-temporal characteristics and determinants of $\mathrm{PM}_{2.5}$ in the Bohai Rim Urban Agglomeration. Chemosphere, 148, 148, 2016.

25. CHEN L., NG E., AN X., REN C., LEE M., WANG U., HE Z. Sky view factor analysis of street canyons and its implications for daytime intra-urban air temperature differentials in high-rise, high-density urban areas of Hong Kong: a GIS-based simulation approach. Int. J. Climatol., 32, 121, 2012.

26. YANG F., LAU S.S.Y., QIAN F. Urban design to lower summertime outdoor temperatures An empirical study on high-rise housing in Shanghai. Build. Environ., 46, 769, 2011.

27. ZENG H., CHEN L.D., DING S.Y. Landscape ecology. Beijing. Higher Education Press 2017 [In Chinese].

28. Specifications for Surface Meteorological Observation. GB/T 35237-2017. The China Meteorological Administration 2017 [In Chinese].

29. XU X.H., ZHANG T.C. Spatial-temporal variability of $\mathrm{PM}_{2.5}$ air quality in Beijing, China during 2013-2018. J. Environ. Manage., 262, 110263, 2020..

30. LI S., SHI T.M., ZHOU S.W., GONG J.P., ZHU L., ZHOU Y. Diffusion Effects of Atmospheric Pollutants on the Three Dimensional Landscape Pattern of Urban Block. J. Shenyang Jianzhu Univ. (Nat. Sci.), 32, 1111, 2016 [In Chinese].

31. LU D., MAO W., YANG D., ZHAO J., XU J. Effects of land use and landscape pattern on $\mathrm{PM}_{2.5}$ in Yangtze River Delta, China. Atmos. Pollut. Res., 9, 705, 2018.

32. XIE W.D., WU J.S. Effects of land use and urban landscape pattern on $\mathrm{PM}_{2.5}$ concentration: A Shenzhen case study. Acta Sci. Natur. Univ. Pekinensis, 53, 160, 2017 [In Chinese].

33. OU W.X., ZHANG Z., TAO Y. Multi-scale correlation analysis of urban landscape pattern and $\mathrm{PM}_{2.5}$ concentration in the Yangtze River Delta. China Popul. Resour. Environ., 29, 11, 2019 [In Chinese].

34. SU W., LAI X.Y., LAI S.N., LIU Y.Q., ZHANG Z.J., ZHANG S.J., HUANG G.X., GU X.R. Spatiotemporal variations of atmospheric $\mathrm{PM}_{2.5}$ and $\mathrm{PM}_{10}$ in Nanchang and its correlation with landscape pattern. Chinese Acta Sci. Circumst., 40, 2431, 2017 [In Chinese].

35. WANG G.Y., BAI W.L., LI X.Y., ZHAO S.T. Research of greenbelt design technology on $\mathrm{PM}_{25}$ pollution reduction in Beijing. Chinese Landsc. Architect., 30, 70, 2014 [In Chinese].

36. HONG B., LIN B., QIN H. Numerical Investigation on the Effect of Avenue Trees on $\mathrm{PM}_{2.5}$ Dispersion in Urban Street Canyons. Atmosphere, 8, 129, 2017.

37. SUN F.Y., LIU M., WANG Y.C., WANG H., CHE Y. The effects of 3D architectural patterns on the urban surface temperature at a neighborhood scale: Relative contributions and marginal effects. J. Cleaner Prod., 258, 120706, 2020.

38. YANG J., SU J., XIA J., JIN C., LI X., GE Q. The impact of spatial form of urban architecture on the urban thermal environment: a case study of the Zhongshan district, Dalian, China. IEEE J-STARS., 11, 2709, 2018. 
39. LIU Y., CHEN C., LI J., CHEN W.-Q. Characterizing three dimensional (3-D) morphology of residential buildings by landscape metrics. Landsc. Ecol., 35, 2587, 2020.

40. ZHENG Z., ZHOU W., YAN J., QIAN Y., WANG J., LI W. The higher, the cooler? Effects of building height on land surface temperatures in residential areas of Beijing. Phys. Chem. Earth., 110, 149, 2019.

41. ALAVIPANAH S., SCHREYER J., HAASE D., LAKES T., QURESHI S. The effect of multi-dimensional indicators on urban thermal conditions. J. Clean. Prod., 177, 115, 2018.

42. LOU C.R., LIU H.Y., LI Y.L., LI Y.F. Research on the response of air particles $\left(\mathrm{PM}_{25}, \mathrm{PM}_{10}\right)$ to landscape structure:A review. Chinese Acta Ecol. Sinica, 36, 6719, 2016 [In Chinese].

43. QIAO Z., WU F., XU X.L., YANG J., LIU L. Mechanism of spatiotemporal air quality response to meteorological parameters: A national-scale analysis in China. Sustainability, 11, 3957, 2019.

44. FAN S.X., LI X.P., DONG L. Field assessment of the effects of land-cover type and pattern on $\mathrm{PM}_{10}$ and $\mathrm{PM}_{25}$ concentrations in a microscale environment. Environ. Sci. Pollut. Res., 26, 2314, 2019.

45. HOEK G., EEFTENS M., BEELEN R., FISCHER P., BRUNEKREEF B., BOERSMA K.F., VEEFKIND P. Satellite $\mathrm{NO}_{2}$ data improve national land use regression models for ambient $\mathrm{NO}_{2}$ in a small densely populated country. Atmos. Environ., 105, 173, 2015.

46. GOSMAN A.D. Developments in CFD for industrial and environmental applications in wind engineering. J. Wind Eng. Ind. Aerodyn., 81, 21, 1999.

47. JONES S.G., FISHER B.E.A., GONZALEZ-FLESCA N., SOKHI R. The use of measurement programmes and models to assess concentrations next to major roads in urban areas. Environ. Monit. Assess., 64, 531, 2000.

48. BENSON P.E. Review of the development and application of the CALINE3 and CALINE4 models. Atmos. Environ., 26, 379, 1992.

49. EERENS H.C., SLIGGERS C.J., VAN DEN HOUT S.D. The CAR model: the Dutch method to determine citystreet air quality. Atmos. Environ., 27, 389, 1993.

50. JOHNSON W.B., LUDWIG F.L., DABBERDT W.F., ALLEN R.J. An urban diffusion simulation model for carbon monoxide. J. Air Pollu. Contr., 23, 490, 1973.

51. HERTEL O., BERKOWICZ R. Modelling pollution from traffic in a street canyon. Evaluation of data and model development, NERI, Roskilde, Denmark. 1989.

52. VARDOULAKIS S., FISHER B.E., PERICLEOUS K., GONZALEZ-FLESCA N. Modelling air quality in street canyons: a review. Atmos. Environ., 37, 155, 2003.

53. SAIDE P.E., CARMICHAEL G.R., SPAK S.N., GALLARDO L., OSSES A.E., MENA-CARRASCO M.A., PAGOWSKI M. Forecasting urban $\mathrm{PM}_{10}$ and $\mathrm{PM}_{2.5}$ pollution episodes in very stable nocturnal conditions and complex terrain using WRF-Chem CO tracer model. Atmos. Environ., 45, 2769, 2011.

54. GONG J.P., HU Y.M., LIU M., BU R.C., CHANG Y., BILAL M., LI C.L., WU W., REN B.H. Land Use Regression Models Using Satellite Aerosol Optical Depth Observations and 3D Building Data from the Central Cities of Liaoning Province, China. Pol. J. Environ. Stud., 25, 1015, 2016.

55. LIU Y.S., MIAO S.G., ZHANG C.L., CUI G.X., ZHANG Z.S. Study on micro-atmospheric environment by coupling large eddy simulation with mesoscale model. J. Wind Eng. Ind. Aerodyn., 107, 106, 2012.
56. GAO Y., WANG Z.Y., LU Q.C., PENG Z.R. Estimation of Vertical Concentrations of Fine Particulates Alongside an Elevated Expressway. J. Shanghai Jiaotong Univ., 52, 650, 2018 [In Chinese].

57. EICHHORN J., KNIFFKA A. The numerical flow model MISKAM: State of development and evaluation of the basic version. Meteorol. Z., 19, 81, 2010.

58. EICHHORN J. Validation of a microscale pollution dispersal model. In book: Air Pollution Modeling and Its Application XI, 539, 1996.

59. ZHOU S.W., TANG R.L., ZHANG Y.X., MA K.M. A review of air pollutant diffusion models for urban street. Chinese J. Appl. Ecol., 28, 1039, 2017 [In Chinese].

60. PAAS B., SCHNEIDER C. A comparison of model performance between ENVI-met and Austal2000 for particulate matter. Atmos. Environ., 145, 392, 2016.

61. CAI H., XU X. Impacts of built-up area expansion in 2D and $3 \mathrm{D}$ on regional surface temperature. Sustainability, $\mathbf{9}$, 1862, 2017.

62. SOUCH C., GRIMMOND S. Applied climatology: Urban climate. Prog. Phys. Geog., 30, 270, 2006.

63. LATEB M., MERONEY R.N., YATAGHENE M., FELLOUAH H., SALEH F., BOUFADEL M.C. On the use of numerical modelling for near-field pollutant dispersion in urban environments: A review. Environ. Pollut., 208, 271, 2016.

64. BLOCKEN B. Computational fluid dynamics for urban physics: Importance, scales, possibilities, limitations and ten tips and tricks towards accurate and reliable simulations. Build. Environ., 91, 219, 2015.

65. LI X.X., LIU C.H., LEUNG D.Y.C., LAM K.M. Recent progress in CFD modelling of wind field and pollutant transport in street canyons. Atmos. Environ., 40, 5640, 2006.

66. ZHOU Y., CHANG L.C., CHANG F.J. Explore a Multivariate Bayesian Uncertainty Processor driven by artificial neural networks for probabilistic $\mathrm{PM}_{2.5}$ forecasting. Sci. Total Environ., 711, 134792, 2020.

67. CHUDNOVSKY A.A., KOSTINSKI A., LYAPUSTIN A., KOUTRAKIS P. Spatial scales of pollution from variable resolution satellite imaging. Environ. Pollut., 172, 131, 2013.

68. ENGEL-COX J.A., HOLLOMAN C.H., COUTANT B.W., HOFF R.M. Qualitative and quantitative evaluation of MODIS satellite sensor data for regional and urban scale air quality. Atmos. Environ., 38, 2495, 2004.

69. GUPTA P., KHAN M.N., DA SILVA A., PATADIA F. MODIS aerosol optical depth observations over urban areas in Pakistan: quantity and quality of the data for air quality monitoring. Atmos. Pollut. Res., 4, 43, 2013.

70. WILSON J.G., ZAWAR-REZA P. Intraurban-scale dispersion modelling of particulate matter concentrations: Applications for exposure estimates in cohort studies. Atmos. Environ., 40, 1053, 2006.

71. SHI T., DIRIENZO N., REQUIA W.J., HATZOPOULOU M., ADAMS M.D. Neighbourhood scale nitrogen dioxide land use regression modelling with regression kriging in an urban transportation corridor. Atmos. Environ., 223, 117218, 2020.

72. SHI T., HU Y.M., LIU M., LI C.L., ZHANG C.Y., LIU C. Land use regression modelling of $\mathrm{PM}_{2.5}$ spatial variations in different seasons in urban areas. Sci. Total Environ., 743, 140744, 2020.

73. GROSS G. On the Parametrization of Urban Land Use in Mesoscale Models. Boundary Layer Meteorol., 150, 319, 2014. 
74. YUAN C., NG E., NORFORD L.K. Improving air quality in high-density cities by understanding the relationship between air pollutant dispersion and urban morphologies. Build. Environ., 71, 245, 2014.

75. SALAMANCA F., MARTILLI A. A new Building Energy Model coupled with an Urban Canopy Parameterization for urban climate simulations-part II. Validation with one dimension off-line simulations. Theor. Appl. Climatol., 99, 345, 2010.

76. CARRUTHERS D.J., SEATON M.D., MCHUGH C.A., SHENG X.Y., SOLAZZO E., VANVYVE E. Comparison of the Complex Terrain Algorithms Incorporated into Two Commonly Used Local-Scale Air Pollution Dispersion Models (ADMS and AERMOD) Using a Hybrid Model. J. Air Waste Manage. Assoc., 61, 1227, 2011.

77. BEEVERS S.D., KITWIROON N., WILLIAMS M.L., KELLY F.J., ANDERSON H.R., CARSLAW D.C. Air pollution dispersion models for human exposure predictions in London. J. Exposure Sci. Environ. Epidemiol., 23, 647, 2013.

78. PENG J., WANG Y.L., ZHANG Y., YE M.T., WU J.S. Research on the influence of land use classification on landscape metrics. Chinese Acta Geogr. Sinica, 61, 157, 2006 [In Chinese].

79. FALLAH-SHORSHANI M., SHEKARRIZFARD M., HATZOPOULOU M. Integrating a street-canyon model with a regional Gaussian dispersion model for improved characterisation of near-road air pollution. Atmos. Environ., 153, 21, 2017.

80. CHEN L.D., LIU Y., LV Y.H., FENG X.M., FU B.J. Landscape pattern analysis in landscape ecology: current, challenges and future. Chinese Acta Ecol. Sinica, 5521, 2008 [In Chinese].

81. LUAN Q.Z., JIANG W., LIU S., GUO H.X. Impact of urban 3D morphology on particulate matter $2.5\left(\mathrm{PM}_{2.5}\right)$ concentrations: Case study of Beijing, China. Chinese Geogr. Sci., 30, 294, 2020.

82. LI S., ZHU L., SHI T.M., WANG W. The counter measures of urban street planning based on the pollution prevention of inhalant partical. Chinese Urban Dev. Stud., 21, 42, 2014 [In Chinese].

83. LUAN Q.Z., LI B., YE C.H., ZHANG X.S., ZHANG Y. Preliminary analysis about impacts of urban 3D landscape pattern on regional meteorological condition in Beijng. Chinese Ecol. and Environ. Sci., 28, 514, 2019 [In Chinese].

84. LIU M., HU Y.M., LI C.L. Landscape metrics for threedimensional urban building pattern recognition. Appl. Geogr., 87, 66, 2017.

85. TR O. Canyon geometry and the nocturnal urban heat island: Comparison of scale model and field observations. J. Climatol., 1, 237, 1981.
86. STEWART I.D., OKE T.R. LOCAL CLIMATE ZONES FOR URBAN TEMPERATURE STUDIES. Bull. Am. Meteorol. Soc., 93, 1879, 2012.

87. GÁL T., UNGER J. A new software tool for SVF calculations using building and tree-crown databases. Urban Clim., 10, 594, 2014V

88. LI M., ZANG S.Y., WU C.S., NA X.D. Spatial and temporal variation of the urban impervious surface and its driving forces in the central city of Harbin. J. Geogr. Sci., 28, 323, 2018V

89. YUAN C., NORFORD L., BRITTER R., NG E. A modelling-mapping approach for fine-scale assessment of pedestrian-level wind in high-density cities. Build. Environ. 97, 152, 2016.

90. CHEN T., LIU M., HU Y.M., CHANG X.K., LI C.L., XU Y.Y., SHI T. Differentiation characteristics of threedimensional landscape pattern in Shenyang. Chinese J. Ecol., 34, 2621, 2015 [In Chinese].

91. ZHOU Y., SHI T.M., HU Y.M., LIU M. Study on green space landscape pattern optimization based on urban climatic environment features. China City Plann. Rev., 38, 83, 2014 [In Chinese].

92. WU J., XIE W., LI W., LI J. Effects of Urban Landscape Pattern on $\mathrm{PM}_{2.5}$ Pollution-A Beijing Case Study. Plos One, 10, 2015.

93. KIM S.U., KIM K.Y. Physical and chemical mechanisms of the daily-to-seasonal variation of $\mathrm{PM}_{10}$ in Korea. Sci. Total Environ., 712, 136429, 2020.

94. WANG Z.Y., CAI M., PNEG Z.R., GAO Y. Spatiotemporal distributions of roadside $\mathrm{PM}_{2.5}$ and $\mathrm{CO}$ concentrations based on mobile observations. Chinese Environ. Sci., 37, 4428, 2017 [In Chinese].

95. VOS P.E.J., MAIHEU B., VANKERKOM J., JANSSEN S. Improving local air quality in cities: To tree or not to tree? Environ. Pollut., 183, 113, 2013.

96. WANIA A., BRUSE M., BLOND N., WEBER C. Analysing the influence of different street vegetation on traffic-induced particle dispersion using microscale simulations. J. Environ. Manage., 94, 91, 2012.

97. HU M.G., JIA L., WANG J.F., PAN Y.P. Spatial and temporal characteristics of particulate matter in Beijing, China using the empirical mode decomposition method. Sci. Total Environ., 458-460, 70, 2013.

98. YANG X.Y., LI Y.G., YANG L. Predicting and understanding temporal $3 \mathrm{D}$ exterior surface temperature distribution in an ideal courtyard. Build. Environ., 57, 38, 2012.

99. LIU Y.P., WU J.G., YU D.Y., MA Q. The relationship between urban form and air pollution depends on seasonality and city size. Environ. Sci. Pollut. Res., 25, 15554, 2018. 